\title{
WHO HELP IRREGULAR MIGRANTS? SUPPORTERS OF IRREGULAR MIGRANTS IN AMSTERDAM (THE NETHERLANDS) AND TURIN (ITALY)
}

\author{
Quem ajuda os migrantes irregulares? \\ Partidários de migrantes irregulares em Amesterdão \\ (Países Baixos) e Turim (Itália)
}

\author{
Minke Hajer* \\ Maurizio Ambrosini*
}

\begin{abstract}
Supporters of irregular migrants play an important role in the interactions between irregular migrants and the state. This article aims to shed light on the variety of actors involved in the support of irregular migrants and what kind of help they provide. The article asks whether this kind of help should be seen as purely humanitarian or as a form of political action; and describes a scale ranging from practical help to political help. With forms of hybrid help in between, to emphasize how everyday practices can be considered political in subtle or indirect ways.
\end{abstract}

Keywords: irregular migrants; support; civil society; political action; humanitarianism.

Resumo. Os apoiadores de migrantes irregulares desempenham um papel importante nas interações entre migrantes irregulares e o Estado. Este artigo tem como objetivo esclarecer a variedade de atores envolvidos no apoio a migrantes irregulares e que tipo de ajuda eles fornecem. O artigo pergunta se esse tipo de ajuda deve ser visto como puramente humanitário ou como uma forma de ação política; e descreve uma escala que varia de ajuda prática a ajuda política. No meio a formas híbridas de ajuda, enfatiza como as práticas cotidianas podem ser consideradas políticas de maneira sutil ou indireta.

Palavras-chave: migrantes irregulares; apoio; sociedade civil; ação política; humanitarismo.

Post-doc researcher at the University of Milan, Department of Social and Political Sciences. Milan, Italy. E-mail:minke.hajer@unimi.it. Orcid: 0000-0001-7054-137X .

** Professor of Sociology of Migrations at the University of Milan, Department of Social and Political Sciences. Milan, Italy. E-mail: maurizio.ambrosini@unimi.it. Orcid: 0000-0003-1788-8686. 
Irregular migrants ${ }^{1}$ are formally excluded from society. Yet, they often remain physically present in societies and find alternative ways of inclusion. Migration policies can be seen as a dynamic battleground where states declare their commitment to fighting irregular migration but are challenged by irregular migrants' efforts to enter and settle, as well as by actors who support irregular migrant's agency. Supporters play a prominent role as a third party in this interplay between migrants and states. This article focuses on people or organizations who act in favour of migrants and respond to their practical and social needs, for example by providing accommodation or arranging regularization, for moral, political or religious reasons, but not for profit. They are part of the wider category of migrant intermediaries (Ambrosini, 2017), yet we distinguish the supporters from other intermediaries like smugglers and government (affiliated) institutions or civil servants. The article sheds light on the variety of actors involved in the support of irregular migrants and what kind of help is provided to them, and aims to contribute to the discussion on the political meaning of this support.

Nicholls (2011) describes how 'native support organisations' help migrants by providing crucial resources, varying from money to symbolic capital and insider knowledge (Nicholls, 2011, p. 613). Help to irregular migrants doesn't only focus on basic needs; supporters also help with integration, to navigate bureaucracy, and to establish a social network. This help can be provided, by non-governmental organizations (hereafter NGOs) like Doctors without Borders, and civil society organizations (hereafter CSOs) like churches or local grassroots initiatives. Moreover, social movements, social centres ('centri sociali': see Berzano, Gallini, 2000; Ruggiero, 2000), activist networks and citizens unaffiliated to any particular association can also provide help to (irregular) migrants. Due to their status, irregular migrants most often cannot rely on help provided by the state or by local public authorities; most of the help that is given to them is informal (Ambrosini, 2016). Irregular migrants rely more on their networks than those who are regular (Bloch, Sigona, Zetter, 2009), and those with a strong network generally fare better than those without (Van der Leun, 2004, p. 79). NGOs are among the "brokers" of immigration, whose support becomes even more necessary in times of border enforcement: "As migration control and management have become more sophisticated, the demand for brokers is omnipresent at all levels" (Faist, 2014, p. 42). The agency of irregular migrants often consists of finding supporters and obtaining their help or protection. However, increasingly governments have been targeting those who help migrants as lawbreakers, for example,

1 By which we mean those migrants who don't have a formal residence permit, are in an unclear legal condition (e.g. rejected asylum seekers who appealed against the decision) or who have a very limited and/or a precarious legal status in the country in which they sojourn. 
NGOs involved in search and rescue (SAR) operations on the Mediterranean (e.g.: Carrera, Cortinovis, 2019). The fact that supporters become involved, despite legal risks, adds an interesting contribution to the understanding of the interplay between migration policies and social action.

In recent years, several forms of reception activities have been developed by non-public actors (Pries, 2019). Supporters can be 'ordinary citizens' who mobilize spontaneously, for example, the German mobilizations in the summer of 2015 in support of asylum seekers (Fleischmann, 2017; Kleres, 2017). Supporters can also be established NGOs. Leerkes (2016) describes how in the Netherlands NGOs structurally organize a system of 'secondary poor relief' to rejected asylum seekers, providing a very basic level of care. These non-public actors can provide help themselves or, as Schweitzer (2018) highlights, can play a relevant role in granting irregular migrants access to (public) services to which they are formally entitled. An interesting case is the evolution of the support by social movements. While struggling against borders and engaging with political protests for migrants' rights, several social movements have started to organise more practical services for the migrants they struggle for/with politically. Belloni (2016) talks of "welfare from below", in reference to how activists and social movements provide services to irregular migrants who are excluded from official services. For instance by organising shelters in squatted buildings, language schools, health services, legal advocacy, and bureaucratic assistance. To provide an overview, table 1 shows the diverse actors that are involved in providing support to irregular migrants based on existing literature of migrant supporters in Italy and the Netherlands.

Tab. 1 - Typology of supporters to irregular migrants

\begin{tabular}{|c|c|c|c|c|}
\hline & $\begin{array}{l}\text { NGOs and } \\
\text { specialized } \\
\text { organizations }\end{array}$ & $\begin{array}{l}\text { Other CSOs } \\
\text { (associations of } \\
\text { volunteers, churches) }\end{array}$ & $\begin{array}{l}\text { Social movements/ } \\
\text { social centres/ } \\
\text { activist networks }\end{array}$ & $\begin{array}{l}\text { Independent } \\
\text { supporters }\end{array}$ \\
\hline Main activities & $\begin{array}{l}\text { SAR } \\
\text { Reception on the } \\
\text { territory } \\
\text { Specialised services }\end{array}$ & $\begin{array}{l}\text { Language schools } \\
\text { Medical services } \\
\text { Legal advocacy } \\
\text { Bureaucratic } \\
\text { assistance } \\
\text { Provision of basic } \\
\text { assistance }\end{array}$ & $\begin{array}{l}\text { Political protest, } \\
\text { but increasingly } \\
\text { provision of services } \\
\text { (e.g. shelter in } \\
\text { squatted buildings) }\end{array}$ & $\begin{array}{l}\text { Donation of food, } \\
\text { clothes, money } \\
\text { Accommodation } \\
\text { Socialization, leisure }\end{array}$ \\
\hline $\begin{array}{l}\text { Political } \\
\text { engagement }\end{array}$ & $\begin{array}{l}\text { Variable, higher } \\
\text { recently against } \\
\text { harsher closure of } \\
\text { borders }\end{array}$ & $\begin{array}{l}\text { Variable, but } \\
\text { increasingly coupled } \\
\text { with the provision of } \\
\text { services }\end{array}$ & $\begin{array}{l}\text { Main focus (no } \\
\text { borders movements) }\end{array}$ & $\begin{array}{l}\text { Variable, often } \\
\text { relevant as the } \\
\text { reason to mobilise }\end{array}$ \\
\hline
\end{tabular}




\begin{tabular}{|l|l|l|l|l|}
\hline Formalization & $\begin{array}{l}\text { High (formal } \\
\text { organizations, } \\
\text { contracts with public } \\
\text { authorities) }\end{array}$ & $\begin{array}{l}\text { Mix of formal } \\
\text { structures and } \\
\text { informal activities }\end{array}$ & $\begin{array}{l}\text { Low (self- } \\
\text { organization) }\end{array}$ & $\begin{array}{l}\text { Low (spontaneous } \\
\text { mobilization) }\end{array}$ \\
\hline $\begin{array}{l}\text { Human } \\
\text { resources }\end{array}$ & $\begin{array}{l}\text { Mainly professionals, } \\
\text { volunteers as } \\
\text { supplementary } \\
\text { resources }\end{array}$ & $\begin{array}{l}\text { Variable, often } \\
\text { volunteers }\end{array}$ & Militants/volunteers & Only volunteers \\
\hline
\end{tabular}

\section{Is help to irregular migrants political?}

Humanitarian help can be necessary to save lives. Yet it can also be seen as problematic. Some scholars argue that humanitarianism goes hand in hand with neoliberalism when non-governmental actors effectively 'take over tasks of the state'. Fassin (2005, p. 382), recalling Agamben (1997), states: "The increasing confusion between the humanitarian and the political is a structural feature of contemporary biopolitics". Anderson (2016) even sees the activities of NGOs as part of the border security industry (Andersson, 2016, p. 1061-1062). However, this criticism also concerns the services that humanitarian actors provide to irregular immigrants after their arrival in Europe. According to critics, service-oriented NGOs are functional to the system, because these organizations, despite their good intentions, allow states to continue to exhibit rhetoric of closure without facing the inhumane consequences of such policy. From this angle, NGOs can be depicted as co-opted in "hegemonic neoliberalism, despite their façade of opposition" (Castañeda, 2007, p. 20). Their activities may even create consent for exclusionary policies by preventing highly visible human rights infringements that might entail "a human rights fiasco" (Castañeda, 2007, p. 20).

Yet, the dispute over NGOs saving lives and carrying people to Europe against the will of governments has revealed that "humanitarian" actors also have visions, priorities and values that are not aligned with those of governments and can act in ways that diverge from governments' objectives. They have repeatedly transgressed limitations in rescue activities and prioritized endangered human lives over the enforcement of state sovereignty (Bevilacqua, 2019, p. 17-18). Interestingly, Cuttitta (2018) has nuanced his position, stating that the humanitarian action of NGOs engaged in Search and Rescue (SAR) activities (MSF and Sea-Watch) fluctuate between depoliticization and repoliticization. Irrera (2016) has also shown how, in the so-called 'refugee crisis' in the Mediterranean, NGOs have developed a mix of both political and practical activities, of conflict and cooperation in their relations with EU authorities.

National and local governments can be seen to struggle against the activities of NGOs, volunteers and other civil society actors in favour of asylum 
seekers; and try to delegitimize or even criminalize the help to migrants: not only SAR activities on the Mediterranean but, for instance, also providing food to asylum seekers settled in Paris, which Queirolo Palmas (2017) has referred as an ordinance "against solidarity". Or, the cases of supporters charged with criminal offences in Italy and France after helping migrants in transit, which Fontanari called: the "criminalization of solidarity" (Fontanari, 2017, p. 31).

Amid these different views on migrant support, literature shows how some supporters see their help to migrants as a form of political action, going against the government's inactiveness, or active denial of migrant reception; for instance, the activity of "humanitarian smugglers" who help with border-crossings between Italy and France (Giliberti, 2017). Sandri (2018), talks of "volunteer humanitarianism" of "grassroots organizations" at the so-called Jungle of Calais, whose services have political meaning as: "it stands as a symbol against the strict and violent policies of migration across Europe" (Sandri, 2018, p. 66). These grassroots organisations can start from humanitarian concerns, and not by activism, but they do contest states and border regimes (Sandri, 2018, p. 76).

Yet many supporters, political activists and social movements aside, frame their help to migrants as apolitical, and purely humanitarian (Sinatti 2019). Fleischman and Steinhilper (2017) state that help to irregular migrants used to be a niche activity of either churches or political activists. As help to migrants has become more mainstream, new supporters do not identify themselves as political activists or their help as a religious charity. Rather, they frame their help as ordinary citizens with humanitarian concerns, often avoiding explicit political contextualization (Fleischmann, Steinhilper, 2017). Moreover, this depoliticization could be seen as a response to being accused of political activism. This is most prominently visible in the debate regarding search and rescue missions on the Mediterranean, where lifesaving actions are 'accused' of being political activism. The actors involved, repeatedly emphasize the humanitarian character of their activity (Carola Rakete is a case in point).

How politics is defined, is essential in this discussion. Politics can be defined in narrow terms, as something visible and public done by activists e.g. demonstrations. However, in this article, we aim to see politics as more than only protest. Following Rancière (1999) we argue that the political can be seen as an expression of disagreement and aim to change an existing order in society. In this sense humanitarian help qualifies as political as it attributes value to the human lives the existing order doesn't deem valuable enough to help. With this 'politics of life' (Fassin, 2007) perspective, smaller and subtle acts can also be interpreted as political. 
Sinatti (2019) distinguishes between minimal humanitarianism which depoliticizes, and focuses on mere physical needs or bare life and in effect reduces the migrants to this, and enabling humanitarianism which extends help ranging from focused on mere survival to the incorporation of human rights, democracy promotion and development. Enabling humanitarianism therewith questions the focus on only bare life, and could in this sense be seen as political. However, help to migrants can be practical and necessary to save and sustain migrants in need, while at the same time it can assume a political meaning. A concept like 'direct social action' enables to describe these more 'in-between' actions, by speaking of: "actions that do not primarily focus upon claiming something from the state or other power-holders but that instead focus upon directly transforming some specific aspects of society by means of the action itself" (Zamponi, 2017, p. 97).

Direct social actions can be political and humanitarian at the same time. Moreover, participation in civil support initiatives can also lead to activism; persons who become active out of a sense of humanitarianism can politicize when they learn more about the broader context of the 'refugee crisis' (Pries, 2019; Sinatti, 2019). The 'expertise' they have gained through their support can then even become a vessel in the expression of legitimate political claims (Zamponi, 2017).

This article proposes to see help to migrants as entangled with political action, yet not all help is equally political. We discuss the help to irregular migrants, observed in Amsterdam and Turin, on a scale from the more practical help to political help. Meaning that while all help to migrants could, in a way, be seen as political, some forms of help have a more practical focus, providing food, shelter, healthcare, and others have a more political or activist focus. Both ends of the scale are intended to be analytical rather than empirical since as we showed above help to irregular migrants could in most cases be seen as a combination of both political and practical help. For reasons of clarity, however, the article will discuss the forms of help separately.

\section{Methodology}

This article is based on research at two groups of irregular migrants and their network of supporters, in two cities: Amsterdam, the Netherlands and Turin, Italy. Both groups squat buildings, collaborate with citizens and activist networks, and their efforts have caused them public visibility. Because of this, they might not be representative of irregular migrants as a whole, but provide an interesting case study into the current phenomenon of collective action of irregular migrants, and the help they get from supporters. 
The Amsterdam group consisted of approximately 200 irregular migrants, mostly denied asylum seekers from Eritrea, Ethiopia, Sudan, Somalia, and some from West African countries. The Turin group consisted of approximately 1200 migrants in various stages of (ir-)regularity; both denied asylum seekers and migrants with a humanitarian residence permit, mostly from Mali, Senegal, Somalia and Sudan. The fieldwork consisted of eight months of regular participant observations, of day-to-day activities, meetings with supporters, demonstrations and evictions in each city. During which the researcher presented herself as a researcher while participating in supporting activities, like teaching English and language editing of flyers. The observations were supplemented by 32 interviews with migrants and supporters. Interviews were conducted in Dutch, Italian and English; displayed quotes were translated by the author.

\section{Who help irregular migrants and how?}

Based on the fieldwork, we observed different types of help provided to irregular migrants. This can be seen as a scale ranging from more practical help, support that helps in survival and basic needs, to political help, and many activities in between, the hybrid help. Due to the specific settings in which this research was conducted (migrant squats), the research focused more on the activist networks and the independent supporters. Yet, this paper recognizes that their activities cannot be understood without the presence of civil society organizations that tend to keep more to the background. Moreover, activists and independent supporters work together with organizations and align their activities to what help already exists, and they continuously inform and learn from each other. Categories can overlap over time, for example, supporters can get into contact with the group of irregular migrants through a volunteer mission of their church, yet remain to help the group when that specific activity is over. Table 2 provides an overview of the different supporters and the types of activities they perform as they will be discussed below.

Tab. 2 - Overview of actors involved in helping irregular migrants and the kind of help they provide

\begin{tabular}{|l|l|l|l|l|}
\hline Help & NGO's & Other CSO's & $\begin{array}{l}\text { Social movements/ } \\
\text { social centres/ activist } \\
\text { networks }\end{array}$ & $\begin{array}{l}\text { Independent } \\
\text { supporters }\end{array}$ \\
\hline Practical & Shelter & Shelter & $\begin{array}{l}\text { Juridical \& medical } \\
\text { help (IT) }\end{array}$ & Buddies \\
& Medical help & Additional shelter & Moral support \\
& Juridical help & Moral or religious support & & $\begin{array}{l}\text { Guides in } \\
\text { bureaucracy }\end{array}$ \\
\hline
\end{tabular}




\begin{tabular}{|c|c|c|c|c|}
\hline Hybrid & $\begin{array}{l}\text { Courses } \\
\text { Help with em- } \\
\text { ployment (IT) }\end{array}$ & $\begin{array}{l}\text { Activation activities } \\
\text { Cultural/art projects }\end{array}$ & $\begin{array}{l}\text { Shelter (through } \\
\text { squatting) } \\
\text { Facilitating political } \\
\text { activities }\end{array}$ & $\begin{array}{l}\text { Language courses } \\
\text { Integration } \\
\text { through courses } \\
\text { and interaction }\end{array}$ \\
\hline Political & Official rapports & $\begin{array}{l}\text { Lobbying } \\
\text { Monitoring }\end{array}$ & $\begin{array}{l}\text { Demonstrating } \\
\text { Help with government } \\
\text { contact } \\
\text { Informing the public } \\
\text { (through alternative }{ }^{1} \\
\text { and social media) }\end{array}$ & $\begin{array}{l}\text { Lobbying } \\
\text { Demonstrating } \\
\text { Informing the } \\
\text { public (through } \\
\text { official and social } \\
\text { media) }\end{array}$ \\
\hline
\end{tabular}

${ }^{1}$ In this paper the term alternative media is used to indicate alternative or left wing media outlets like indymedia in the Netherlands and hurreya in Italy

\section{Practical help}

Once a week the 'zorgbus', a bus with a mobile clinic inside, operated by Doctors of the World visits the squats in Amsterdam. Everyone is allowed to enter and discuss health issues. In a promo video one of the medical volunteers who works in the zorgbus states: This volunteer work gives me a lot of gratification. I know that for this target group [undocumented migrants] we can really make a difference with the 'care bus' (...) on the area of medical help if we do not visit these people, no one visits these people.

A substantial portion of the help to irregular migrants is practical help. The main focus of this help is to help irregular migrants survive; like making sure those who are sick get medical help or those who are homeless are provided shelter. Any potential political message that comes with these activities is of secondary importance. Practical help is mostly provided by established NGOs or CSOs. These organizations can provide more structural and fundamental aid because of their degree of professionalization. They have the resources to provide long term and structural help, which can be of vital importance for irregular migrants in whose lives so many things are fundamentally insecure. They are, for example, able to provide adequate and long-term shelter for those in vulnerable positions, provide actual medical care or professional psychological support. An example of structural practical support is the 'day shelter' organized by the Wereldhuis in Amsterdam, a place where all irregular migrants, those who live on the street or have a bed in a shelter or who live in squats, can come during the day. They can have a hot meal, recharge their phone, and if they want they can access various services and courses. Another example is the helpdesk of Doctors without Borders in Turin, who visit the squats every week on set days. Moreover, religious institutions, in particular migrant churches like the Eritrean Orthodox Church in Amsterdam, and mosques provide an important role in the form of religious guidance. Many irregular migrants attend services regularly and find support and comfort there. 
Independent supporters provide practical help mostly by functioning as a personal 'buddy' to an irregular migrant. In Amsterdam, this was somehow formalized in a 'buddy project' where an irregular migrant was linked to a supporter for a set amount of time, and the supporter could receive some training from other more experienced supporters. In Turin, there were more informal buddies. Buddies could be essential to tackle bureaucracy. An accumulation of struggles, large struggles like being irregular in general and an array of smaller ones like having a toothache, make bureaucracy a huge problem of irregular migrants. Both in Turin and Amsterdam migrants have the right to certain (mostly medical) facilities regardless of their status, on paper. However, in practice, it was often so difficult to actually obtain these services that irregular migrants end up at NGOs, CSOs or other supporters to help them obtain the services they need. It was a common practice for native supporters or experienced migrants who turned into cultural mediators, to accompany irregular migrants to all sorts of services. As can be seen in the fragment below:

all these steps we had to take [to see a medical specialist], and all these offices we had to go to, if he would have gone alone he would have left already. He would have thought that the help didn't exist. When I come along I assure him that people aren't lying. And in the end, we did get to see a doctor. (Supporter in Amsterdam)

Bringing a supporter to an appointment proved to be effective since supporters spoke the language, knew which buttons to push, how to gain the right information, and knew when to make a fuss and when not to. Buddies also tended to help find odd-jobs for irregular migrants, helping them earn some money working in the garden of an elderly family member or cleaning houses of their fellow parishioners. Moreover, buddies can function as a source of moral support or informal counselling. In Amsterdam, buddies played a big role in (renewed) asylum procedures, and rumours spread among the irregular migrants about which buddies were the best or most effective. Moreover, there were also one-time buddies, where a supporter would accompany a migrant to an important appointment for example to handle residence permit applications, to resolve some problems with the Questura ${ }^{2}$, or to accompany them to a medical appointment.

Furthermore, social centres and activists networks could also be seen to help the irregular migrants in practical ways and not only politically. In Italy, social centres were places to borrow resources, like a DJ set to use at a solidarity party, or chairs to use during a meeting. In Amsterdam, the squatter's movement provided reusable locks that could be used to secure rooms in squatted buildings.

Italian state police, issues the residence permits. 


\section{Hybrid forms of help}

[A lesson at the school in the squat] This week Manuela (teacher) pretends to be a civil servant sitting behind a desk. "Ask me for something", someone asks something. Manuela looks at him angry then, with a long sigh, nods her head in a what-do-you-want kind of way; he asks again, another sigh. Then she jumps out of her role: "I'm not being racist here! This is how they treat everyone! Also us!" and she points to the Italians, they nod. "Civil servants are just like that, like they don't want to help you, but they are not racist, or maybe they are but eh... well. But they treat everyone like this! The important thing is that you remain nice and compose yourself. (Fragments from field notes - Turin)

Many activities of supporters weren't obvious instances of political or practical help but were hybrid forms. The fragment above shows a lesson at the school within the squat. Some weeks before the teachers decided the school could teach much more than language alone, as things like grammar were also taught at the schools for adult education that many of the migrants also attended. The teachers at this school, mostly individual supporters that started organizing lessons together, decided to add more practical knowledge to their lessons, which they found equally important as speaking Italian. These lessons taught irregular migrants about dealing with society. By transferring the local knowledge needed to be able to enact the modes appropriate of being a citizen (Isin, Nielsen, 2008), these lessons could also be seen as integrating people that ought to be excluded. Which could be seen as a political act, as it goes against the dominant order. Moreover, teaching irregular migrants how to compose themselves in society goes against a system that benefits from irregular migrants lacking the ability to obtain basic services. One could see these activities as being in-between practical and political help. The activities were often intended to be practical (language classes) or fun (cultural evenings). While at the same time they are political because actively helping those officially excluded get included explicitly goes against official policies, and it isn't primarily focused on mere survival.

NGOs and CSOs also provide hybrid forms of help. For example language and vocational classes, art projects and meetings for cultural expression, often aim to activate or re-activate irregular migrants, or to facilitate contact between irregular migrants and established citizens. However, at the same time, they help irregular migrants to create their place in society or to integrate. They create spaces of hospitality in an otherwise hostile environment for irregular migrants.

They have lost their mama Africa, and now they are looking for a new frame of reference, we help them with that. (Volunteer at civil society organization - Turin)

Irregular migrants considered these safe spaces valuable as they could let their guard down and feel accepted or integrated for the duration of the activity. 
I'm an actor now; I'm part of a theatre group. So I'm no longer only undocumented. (Aziz - Amsterdam)

When I go to 'migrant art' I feel that I can be myself, I feel integrated you know because people treat me as equal. (Samba - Turin)

It could be said that social centres, activists and squatters movements are primarily focused on the political side of the support. However, while doing this they provide an important part of practical help, namely housing. Activists played a crucial role in the squatting of buildings the irregular migrants live in. In Turin this concerned one large complex, and in Amsterdam, this concerned more than 40 buildings over the course of several years. Activists would also help with the maintenance of the buildings, fixing broken electrics, changing locks, and building showers in squatted office buildings or churches.

Squatting can be seen as inherently political, as 'reclaiming' space for marginalized groups in the city making a political statement. But squatting is also a practical way of helping irregular migrants in need of shelter; many irregular migrants living in these squats would otherwise sleep on the streets. For them squatting is a practical solution first and a possible political statement second. It could, therefore, be seen as a hybrid form of help where the political and the practical are combined. Activists often did not distinguish between political claim-making and the help they provide to migrants. Supporters, in general, indicated that while their help might not be directly political, their motivations to help where political. The forms of hybrid help as described above show how help or support can appear as mostly practical but can still have political meaning and/or function; or the other way around.

\section{Political help}

We stand on one of the main squares of the city; the turnout of this demonstration is low. About 30 people stand in a circle, in the middle a speaker, one by one people speech through a microphone. (...) After 45 minutes the demonstration is about to end. 'How do we end the demonstration?' someone asks, 'I think we should sing Bella Ciao' someone says. Everyone agrees this is a good idea, yet no one seems to know the lyrics. After a quick Internet search, they sing the song while reading from a phone. Afterwards, a man with a ponytail helps them to pack the speaker system he had lent them and says 'you know for the next time we will practice the song, because well...' 'But we managed in the end right?' 'You should really learn the lyrics, we should make it more fluent'. (Fragment from field notes - Turin)

In order to make claims to rights and inclusion, irregular migrants benefit from the help of (native) citizens. As protest is influenced by local culture, supporters can function as brokers to political action. This political help is the main activity of activist networks and the social centres in Italy. Activists occupied themselves with the transfer of protest specific local knowledge. They would also help organize demonstrations, make banners, advertise for the demonstrations, help formulate the message, and provided the appropriate 
equipment like megaphones. They would help with the development of the (rights) claims and how to deliver them more effectively. For example, supporters showed irregular migrants how to follow specific norms and values, how to attach their claims to local historical events or politically meaningful places in the city (Hajer, Bröer, forthcoming).

The fragment above shows how the man with the ponytail (an activist) helped a demonstration with both sound equipment and advice on how to make their political acts more culturally legitimate the next time. Singing Bella Ciao could be considered a necessary part of a (left-wing oriented) demonstration in Italy. For irregular migrants to make it part of their message they needed the help of an Italian activist to perfect it. In the Netherlands, for example, Dutch activists guided the irregular migrants through the processes of applying for demonstration permits and teaching them how to apply for these permits themselves.

Moreover, as some forms of political action like squatting also involve civil disobedience, the need for specific local knowledge is even more important, in order to stretch the law while keeping political legitimacy. The experienced activists guided the irregular migrants into how far laws could be stretched, what kind of legal loopholes existed, what kind of tactics police forces used, and how to avoid arrest. In both settings activists played an important role in helping irregular migrants with their contact with important actors like mayors, the police, or the owners of squatted buildings. They would, more specifically, try to convey their specific experiences and knowledge, and try to help irregular migrants understand cultural codes of conduct in specific situations. They would try to estimate and explain the legal possibilities for protest, try to explain the strategies and behaviour of the police and the state/ municipality; mostly related to squatting and demonstrating. This knowledge proved to be useful and quite often the estimations of how for example police would respond to things turned out to be true. While a smaller group of activists would help with organizing and preparing political activities, irregular migrants could count on their larger networks to show up at the events or demonstrations they would organize. For example, when a group of irregular migrants in Amsterdam decided to resist the eviction of their squat, they could count on activists to help block the entrances, and resist the police.

Like the other types of help, political help can come in many different shapes and forms. NGOs and CSOs often weren't very visibly political, yet behind the scenes, they would, for example, advocate and lobby for the cause of irregular migrants in local politics. Moreover, NGOs like Doctors of the World and Doctors without Borders would, by using their status as established NGOs with expertise, help to bring the situation of irregular migrants to the attention of politics and the wider public. For example, by publishing 
official reports about the living conditions and general situation of irregular migrants; or by speaking to politics directly using their position as experts. Another example of ways in which the supporters of irregular migrants would occupy themselves with activism was to monitor the situation of irregular migrants in their community. The various types of supporters would inform each other about the situation of irregular migrants, creating a network of concerned citizens and organizations. Church networks, activist networks and/ or independent supporters of irregular migrants would keep NGOs and CSOs up to date. This could also be instigated by activists, who would now and then do a 'round of parishes' informing churches about new developments, for example when they were anticipating an eviction. Or churches would, for example, ask activists or individual supporters to come and brief them about the current situation. Then a few times a year supporters would use this information to lobby for specific causes of irregular migrants, for example, the need for adequate shelter, at politicians and political parties.

\section{Relations between irregular migrants and their supporters}

Over the years and during many activities irregular migrants and their supporters formed strong bonds; many friendships, romantic relations and other family-like relations were formed. For example, the younger migrants often referred to older female supporters as 'mama', an indication of both closeness and respect. When speaking to irregular migrants about supporters, the majority was positive. Migrants would share how grateful they were, how much certain supporters had helped them, and how they would have never been able to manage on their own.

However, as in any constellation in which a large number of different people have to collaborate, problems arose between irregular migrants and various groups of supporters. The problems varied from minor issues due to clashes of personality's, to larger problems and fights over scarce resources like money. In most instances, the problems originated from differences in motives or differences in power. Moreover, problems were often caused by a mismatch of what was seen as help. The question of how help relates to politics is important here. Many supporters considered their solidarity in itself to be help. Supporters often just came to the squats to chat, drink coffee or smoke a cigarette. The mere fact of spending time at the squat, showing that not everyone is against migrants, interacting with those who are formally excluded was considered by them to be a political act and therefore help to the migrants. However, for many irregular migrants, these practices seemed puzzling, as they often envisioned help in more practical terms. The fragment below shows how for 'Samba' help is concrete and means clothing or Italian lessons, yet solidarity 
or information sharing is considered 'doing nothing'; while these meetings were considered meaningful by the supporters.

I told Samba after class I was going to the meeting of supporters; he asked me why I was going there. I said I was interested in what they were going to do. Samba said he didn't think they were going to do anything, because they never do anything. 'They just talk, talk and talk; but what do they do? Some 'whites' actually do things like the women who organize the clothes, or you, I mean you teach at the school; you guys do something. But what do they do? They just talk'. (Fragment from field notes - Turin)

Moreover, how supporters looked at the issues of irregular migrants influenced what kind of help they gave. Some political activists saw irregular migrants purely as a political issue, and only provided help with activism, or would only help in more militant ways. In some instances, the activists' own anti-establishment political struggle gained the upper hand over the struggle of irregular migrants. As they weren't afraid to be perceived as troublemakers by police, authorities or media, and didn't change this attitude when teaming up with irregular migrant. This often to the discontent of irregular migrants, who try their best to be perceived as 'deserving migrants' (Nicholls, 2013).

I hear screams and when I walk towards it, Joan [supporter] jells at me: 'he hit him!' I see a group of migrants around a cameraman of Pownews ${ }^{3}$. When I come closer I can hear them apologising profusely. Hakim [migrant] tells me one of the activists didn't want them there and tried to break the camera. He shakes his head. Later Joan tells me she told the activist to leave. (Fragment from field notes - Amsterdam)

In general, supporters, as established citizens, have more power: they have more knowledge about society, speak the language, and have an obvious legitimate presence in public space. Irregular migrants don't have this but can benefit from this power by proxy when they team together. However, as Nicholls (2011) describes, the asymmetric distribution of 'social movement resources', produces a structure in which natives play a dominant role in political claimmaking (Nicholls, 2011). Supporters have the power not to share information, or to do something without telling. For irregular migrants, it is very difficult to go against this. When problems arose the power imbalance often played a role. An example comes from Mahmud, who shares:

There was a meeting with the new mayor; he wanted to talk about We Are Here and asked Kees and also the churches to come. Mahmud asked if he could come as well, but Kees refused. I asked why he didn't just go to the meeting. Mahmud: 'You know I wanted to do that, but they did not tell when and where the meeting was, so I couldn't. It makes me angry because it is my life. I want them to talk to me about myself, but then I ask if I can be included but then they don't let me because I'm not a professional. I don't understand, I don't need them to speak for me, I want to speak for myself but they don't let me'. (Fragment from field notes - Amsterdam)

3 Pownews is a right-wing media outlet known for their aggressive interview style. 
The fragment shows the power imbalance between migrants and supporters. These instances of disagreement fed thoughts that supporters didn't actually want to help. Gossip emerged as a strategy of resistance or 'weapons of the weak' (Scott, 2008), regarding alternative motives of supporters: supporters would make money of helping them, wanted sexual relations with migrants, or were simply crazy.

\section{Conclusion}

Supporters help irregular migrants when the state refrains from giving help or actively tries to sabotage the arrival and settlement of migrants. Supporters are a diverse group consisting of established NGOs and CSOs, activist networks and individual citizens. All have different motivations and provide help in different ways. Together these supporters create forms of 'welfare from below' (Belloni, 2016); they help irregular migrants to obtain the services they cannot access, or provide services themselves. Help can range from providing medical care, food and clothes; to moral or religious support, to cultural projects, to helping irregular migrants to develop their political voice and substantiate political claim-making. Supporters therewith play an important role in the interactions between irregular migrants and the state. Through their numerous interactions, various types of friendships, almost family-like bonds and even romantic relations emerge. Yet because of the difficult and emotionally charged circumstances, and unequal power relations, conflicts are not uncommon.

An overarching question of this article was whether or not help to irregular migrants should be considered as political. In light of hostile governmental attitudes towards migrants in general and irregular migrants in particular, help to irregular migrants can easily become political. Yet, many supporters tend to frame their help to irregular migrants as apolitical, or humanitarian. In line with how scholars have interpreted humanitarianism as a 'politics of life' (Fassin, 2007; Sinatti, 2019), we have proposed to interpret politics as something that can be subtle, implicit, and found in the everyday. The fact that several states have illegalized these activities in various ways, and that anti-immigrant movements and political parties overtly attack providers of humanitarian help (Ambrosini, 2020), indirectly confirms the political implications of simple acts of solidarity. We show, however, how help to irregular migrants can be seen on a scale between practical and political help, and argue how help contains a ratio of practical and political help. Within this scale, many activities are hybrid forms that might not appear as political at first but can be political because of their intentions, their implications, or their effects. By valuing lives that are deemed not valuable, forms of practical and hybrid help can be political in their re-humanizing effect on irregular migrants. 


\section{References}

AMBROSINI, Maurizio. From 'Illegality' to Tolerance and Beyond: Irregular Immigration as a Selective and Dynamic Process. International Migration, v. 54, n. 2, p. 144-159, 2016.

AMBROSINI, Maurizio. Why irregular migrants arrive and remain: The role of intermediaries. Journal of Ethnic and Migration Studies, v. 43, n. 11, p. 18131830, 2017.

AMBROSINI, Maurizio. The urban governance of asylum as a "battleground": Policies of exclusion and efforts of inclusion in Italian towns. Geographical Review, p. 1-19, 2020. Published online in early view.

AGAMBEN, Giorgio. Homo sacer. I. le pouvoir souverain et la vie nue. Paris: Seuil, 1997.

ANDERSSON, Ruben. Europe's failed 'fight'against irregular migration: Ethnographic notes on a counterproductive industry. Journal of Ethnic and Migration Studies, v. 42, n. 7, p. 1055-1075, 2016.

BELLONI, Milena. Learning how to squat: Cooperation and conflict between refugees and natives in rome. Journal of Refugee Studies, v. 29, n. 4, p. 506-527, 2016.

BERZANO, Luigi; GALLINI, Renzo. Centri sociali autogestiti a Torino. Quaderni di Sociologia, n. 22, p. 50-79, 2000.

BEVILACQUA, Giorgia. Italy versus NGOs: The controversial interpretation and implementation of search and rescue obligations in the context of migration at sea. The Italian Yearbook of International Law Online, v. 28, n. 1, p. 11-27, 2019.

CARRERA, Sergio; CORTINOVIS, Roberto. Search and rescue, disembarkation and relocation arrangements in the Mediterranean. Sailing away from responsibility? CEPS papes. Brussels: CEPS, p. 1-6, 2019.

CASTAÑEDA, Heide. Paradoxes of providing aid: NGOs, medicine, and undocumented migration in Berlin, Germany. (Doctoral dissertation - PhD). 2007.

CUTTITTA, Paolo. Repoliticization through search and rescue? humanitarian NGOs and migration management in the central Mediterranean. Geopolitics, v. 23, n. 3, p. 632-660, 2018.

FAIST, Thomas. Brokerage in cross-border mobility: Social mechanisms and the (re) production of social inequalities. Social Inclusion, v. 2, n. 4, p. 38-52, 2014.

FASSIN, Didier. Compassion and repression: The moral economy of immigration policies in France. Cultural Anthropology, v. 20, n. 3, p. 362-387, 2005.

FASSIN, Didier. Humanitarianism as a politics of life. Public Culture, v. 19, n. 3, p. 499-520, 2007.

FLEISCHMANN, Larissa. The politics of helping refugees. Emerging meanings of political action around the german 'Summer of welcome'. Mondi Migranti, n. 3, p. 53-73, 2017. 
FLEISCHMANN, Larissa; STEINHILPER, Elias. The myth of apolitical volunteering for refugees: German welcome culture and a new dispositif of helping. Social Inclusion, v. 5, n. 3, p. 17-27, 2017.

FONTANARI, Elena. Within the fractures of Europe. The active role of civil society in support of and against refugees. Mondi Migranti, v. 11, n. 3, p. 23-35, 2017.

GILIBERTI, Luca. La criminalizzazione della solidarietà ai migranti in Val Roja: Note dal campo. Mondi Migranti, n. 3, p. 161-181, 2017.

HAJER, Minke H. J.; BRÖER, Christian. We are here! Claim-making and Claimplacing of Undocumented Migrants in Amsterdam. European Journal for Cultural and Political Sociology, doi:10.1080/23254823.2020.1774911. Forthcoming.

IRRERA, Daniela. Migrants, the EU and NGOs: The practice of non-governmental SAR operations. Romanian Journal of European Affairs, v. 16, n. 3, p. 20-35, 2016.

ISIN, Engin F.; NIELSEN, Greg M. (eds.). Acts of citizenship. London \& New York: Zed Books, 2008.

KLERES, Jochen. Feeling the refugee crisis: Civic mobilizations in Germany. Mondi Migranti, n. 3, p. 137-160. 2017.

LEERKES, Arjen. Back to the poorhouse? social protection and social control of unauthorised immigrants in the shadow of the Welfare State. Journal of European Social Policy, v. 26, n. 2, p. 140-154, 2016.

NICHOLLS, Walter J. Fragmenting citizenship: Dynamics of cooperation and conflict in France's immigrant rights movement. Ethnic and Racial Studies, v. 36, n. 4, p. 611-631, 2011.

NICHOLLS, Walter J. Making undocumented immigrants into a legitimate political subject: Theoretical observations from the united states and france. Theory, Culture \& Society, v. 30, n. 3, p. 82-107, 2013.

PRIES, Ludger. Introduction: Civil society and volunteering in the so-called refugee crisis of 2015 - Ambiguities and structural tensions. In: FEISCHMIDT, Margit; PRIES, Ludger; CANTAT, Celine (eds.). Refugee protection and civil society in Europe. Palgrave Macmillan, p. 1-23, Springer 2019.

QUEIROLO PALMAS, Luca. Nuit debout: transiti, connessioni e contestazioni negli accampamenti urbani dei rifugiati a Parigi. Mondi Migranti, n. 2, p. 207-227, 2017.

RANCIÈRE, Jacques. Disagreement: Politics and philosophy. Minneapolis: University of Minnesota Press, 1999.

RUGGIERO, Vincenzo. New social movements and the 'centri sociali'in Milan. The Sociological Review, v. 48, n. 2, p. 167-185, 2000.

SANDRI, Elisa. 'Volunteer humanitarianism': Volunteers and humanitarian aid in the Jungle refugee camp of Calais. Journal of Ethnic and Migration Studies, v. 44, n. 1, p. 65-80, 2018. 
SCHWEITZER, Reinhard. The micro-management of migrant irregularity and its control: A qualitative study of the intersection of public service provision with immigration enforcement in London and Barcelona (Doctoral thesis - PhD). 2018.

SCOTT, James C. Weapons of the weak: Everyday forms of peasant resistance. Yale university Press, 2008.

SINATTI, Giulia. Humanitarianism as politics: Civil support initiatives for migrants in Milan's hub. Social Inclusion, v. 7, n. 2, p. 139-148, 2019.

VAN der LEUN, Joanne. Lokale solidariteit met illegale migranten. In: ENTZINGER, Han; VAN der MEER, Jelle (eds.). Grenzeloze Solidariteit. Naar een migratiebestendige verzorgingsstaat. Amsterdam: De Balie, 2004, p. 73-85.

ZAMPONI, Lorenzo. Practices of solidarity: Direct social action, politicisation and refugee solidarity activism in italy. Mondi Migranti, v. 3, p. 97-117, 2017. 